\title{
Does Talent Management Affect Employee Performance?: The Moderating Role of Work Engagement*
}

\author{
Sopiah SOPIAH ${ }^{1}$, Didiek Tri KURNIAWAN ${ }^{2}$, Elfia NORA $^{3}$, Bagus Shandy NARMADITYA ${ }^{4}$
}

Received: May 03, 2020 Revised: May 10, 2020 Accepted: June 07, 2020

\begin{abstract}
The study aims to examine the relationship between talent management and work engagement and its impact on nurses' performance in Indonesia. This study is also intended to understand the role of work engagement in moderating talent management and employee performance. This present study applied a quantitative method using path analysis to investigate the relationship between variables and the primary role of work engagement. The participants of the study were nurses both in privates and public hospitals in Indonesia, with a total of 376 respondents. Closed questionnaires were processed in this study with a Likert scale with five choices ranging from 1 (strongly disagree) to 5 (strongly agree). The questionnaires were entirely collected over almost five months using Google form. The results of the study confirmed that the nurse performance, both at government and private hospitals, are categorized as good, while the work engagement and talent management are also categorized as high. The findings confirmed that talent management positively influences work involvement and employee performance. In addition, this study suggests that work engagement plays an essential role in moderating between variables and provides a confirmation of the important role of talent management and work engagement for nurses' performance.
\end{abstract}

Keywords : Work Engagement, Talent Management, Employee Performance, Nurses Performance, Indonesian Hospital

JEL Classification Code: J53, J81, M54, O15

\section{Introduction}

In the last decade, the topic of employee performance has a concern among scholars. The empirical evidence showed that employee performance plays a strategic role in an organization in facing global challenges (Yoon et al., 2019; Schuler et al., 2011). The primary reason is that employee

\footnotetext{
*Acknowledgements:

We are grateful to anonymous referees and editor of the journal for their valuable comments and suggestions an attempt to enhance the quality of article.

${ }^{1}$ First Author and Corresponding Author. Faculty of Economics, Universitas Negeri Malang, Indonesia [Postal Address: Jalan Semarang 5 Malang, 65145, Indonesia] Email: sopiah.fe@um.ac.id ${ }^{2}$ Faculty of Economics, Universitas Negeri Malang, Indonesia. Email: didiek.kurniawan.fe@um.ac.id

${ }^{3}$ Faculty of Economics, Universitas Negeri Malang, Indonesia. Email: elfia.nora.fe@um.ac.id

${ }^{4}$ Faculty of Economics, Universitas Negeri Malang, Indonesia. Email: bagus.shandy.fe@um.ac.id

(c) Copyright: The Author(s)

This is an Open Access article distributed under the terms of the Creative Commons Attribution Non-Commercial License (http://Creativecommons.org/licenses/by-nc/4.0/) which permits unrestricted noncommercial use, distribution, and reproduction in any medium, provided the unrestricted noncommercial use,
original work is properly cited.
}

performance is closely related to productivity and vice versa. Englert and Helmig (2018); Nguyen et al. (2019) noted that the diminishing performance of the employee will relate to the success and failure in an organization. High-level and low-level employee performance can be explained by two dominants factors - talent management and work engagement.

Talent management has become the primary global challenge facing most organizations in the world. The inadequate talent encourages organizations or companies to compete in attracting the same talent to maintain, develop, and achieve effectively and efficiently the organization's goals. Previous studies by Lubitsh and Smith (2007); Ingram and Gold (2016); Nojedeh and Ardabili (2015) stated that effective talent management is one of the critical success factors for organizations to gain a sustainable competitive advantage. Organizational achievement is associated with employee performance. In a situation when employees have unique competencies that cannot be imitated by competitors, the organization has the potential to gain a sustainable competitive advantage. Therefore, to manage this unique human resource, the organization focuses on establishing various aspects, namely, systems, processes and talent management approaches. It includes several efforts to identify opportunities and develop integrated and result-oriented action plans. 
Talent management, not only recruits, strengthens, and evaluates talent, but can also lead to personal growth, employee satisfaction, and improvement in employee performance (Tash et al., 2016). Talent management practices are elaborated as human resource development to gain competitiveness, which is an area of concern for organizations to manage talent effectively and efficiently. There are significant positive effects of talent management practices, including talent development, career development, and work-life balance on employee performance (Bibi, 2019). Meanwhile, Barkhuizen et al. (2014) pointed out that appropriate talent management policies and practices also provide the commitment to an employee, which lead to a greater level of work involvement among workers and potentially diminishing turnover rates.

The number of studies on talent management and employee performance has increased. For example, Alias et al. (2014) found that talent management and work engagement have a relation with employee retention. Aljunabi (2014) concluded that the talent management has a positive impact toward work engagement. Another study by Mogwere (2014) noted that the implementation of work engagement in higher education can predict work involvement. Furthermore, Mensah et al. (2016); Mangusho et al. (2015) remarked that talent management promotes talented employee performance and reduce counterproductive behavior. Tash et al. (2016); Mkamburi and Kamaara (2017) revealed that there is a robust relation between talent management (talent withdrawal, talent care, talent development) on job satisfaction and employee performance. Lastly, Bibi (2019) pointed out that the work engagement dimension mediates the influence of talent management on organizational commitment.

Notwithstanding the increasing attention among researchers, there is a paucity of studies, and several questions on talent management and employment need to be addressed. Although there is an increase in the contribution of talent management to human resources management conceptually, there is still a lack of academic studies on that construction, especially in developing countries. For these reasons, this study intends to examine the deep understanding of talent management and employee performance in hospital organization in Indonesia. This study also provides an understanding of the role of work engagement in moderating the impact of talent management and employee performance. An understanding of the factors affecting employee performance can contribute to enhancing the quality of nurses in hospitals in Indonesia.

\section{Literature Review}

\subsection{Talent Management and Work Engagement}

Talent management plays a crucial role in organizational development, particularly employee development. It consists of the planning process, employee recruitment, employee development, management, and compensation of employees (Dessler, 2015). Aljunabi (2014) added that talent management is indicated by several factors such as talent developments, talent culture recognition, policies, and leadership support. Meanwhile, employee engagement is a process for involving employees at all levels of the company, such as in the process of decision-making and solving company problems. Besides, employee engagement can also increase the sense of belonging and responsibility for decisions by involving employees who are in direct contact with work (Tjiptono \& Diana, 2003). Among several variables, talent management is one of the important aspects whose implementation must be considered by the organization. Talent management relates with employee engagement. Several studies by Hughes and Rog (2008); Aljunaibi (2014); Dhanalakshmi and Gurunathan (2014); Järvi and Khoreva (2019) showed that there is a positive and significant influence of talent management with employee engagement in the organization.

H1: Talent management positively influences work engagement

\subsection{Work Engagement and Employee Performance}

Mathis and Jackson (2006) remarked that performance is determined by ability, motivation, and environmental factors. Employee engagement is closely related to employee performance. Several shreds of evidence by Anitha (2014); Dajani (2015); Carter et al. (2011) showed that there is a positive and significant relationship between self-efficacy and employee involvement with job performance. Also, Anitha (2014) confirmed that employee involvement has a significant impact on employee performance. Numerous studies by Aljunaibi (2014); Alias et al. (2014); Mensah et al. (2016); Tash et al. (2016): Kim and Koo (2017); Al-momani (2018) mentioned that organizations use different approaches to stay competitive and improve performance. Work engagement is characterized by increased employee commitment and excellent organizational performance (Dessler, 2015). Work engagement is an important role to help each organization gain a competitive advantage compared to other human capital. It is one of the factors that cannot be imitated by competitors and is considered the most valuable asset if managed and used correctly (Anitha, 2014). This can be done by improving performance through increasing employee engagement with the company. If employees have a close attachment to the company and work, then they will increase three general behaviors, namely, say, stay, and drive, which means employees will be more effective at work, loyal to the company, and strive to improve their performance. 
Sopiah SOPIAH, Didiek Tri KURNIAWAN, Elfia NORA, Bagus Shandy NARMADITYA /

Journal of Asian Finance, Economics and Business Vol 7 No 7 (2020) 335 - 341

H2: Work engagement positively influences employee performance

\subsection{Talent Management, Work Engagement and Employee Performance}

Talent management is an important program that needs to be implemented by an organization or a company. Talent management is essentially a series of processes carried out by the company to identify, develop, maintain, and place the right people at the right place. Talent management policies can influence work engagement and also improve their performance. Dhanalakshmi and Gurunathan (2014); Mensah et al. (2016) proposed that talent management has a relationship with employee performance, and it is mediated by several factors, such as affection and work engagement as well as how they identify with the company. Besides, Mohammed (2016) remarked that talent management has a relationship with company performance through work engagement. Kamel (2019) noted that talent management is a business strategy in an organization, which potentially promotes organization accomplishment. In other words, when worker or employee has particular competence that is difficult to be adopted by others, the organization will have a competitive advantage over competitors. The results prove that talent management influences company performance through employee involvement. Indeed, Dahshan et al. (2018) believed talent management influences hospital performance, while Al-Qeed et al. (2018) prove that talent management influences company performance through emotional intelligence.

H3: Talent management positively influences employee performance

H4: Talent management positive influences employee performance through work engagement

\section{Research Method}

\subsection{Sample characteristics and data collection}

This study intends to examine the relationship between talent management, work engagement, and employee performance among nurses in Indonesia. The sample of this study comprises 386 nurses, consisting of 183 male and 203 female nurses. As regards the respondents' education level, 62 percent had diploma degree (D3) and 38 percent had bachelor degree. In general, the respondents were in the age bracket of 20 to 45 and had work experience ranging from 5 to 25 years across government and private hospitals in Indonesia. Closed questionnaires were used in this study with a Likert scale with five choices ranging from 1 (strongly disagree) to 5 (strongly agree). The questionnaire was entirely collected over almost five months using Google form.

\subsection{Measurement}

This study engages three main variables, including talent management, employee performance, and work involvement as a mediator variable. To measure employee performance, we adopted indicators from Malthis and Jackson (2006), which consist of work quality, work quantities, work timeliness, work effectiveness, and work attendance. Meanwhile, to understand talent management, we borrowed items from Aljunaibi (2014), which include talent development, recognition talent culture, policies (talent policy), and leadership support. Lastly, to estimate the work engagement, we applied the Utrecht Work Engagement Scale (UWES) instruments from Schaufeli et al. (2002), which include vigor, dedication, and absorption. Furthermore, the data were analyzed using descriptive analysis and inferential analysis (with path analysis). Before the path analysis, the classical assumption test was used; normality test, multicollinearity test, and heteroscedasticity test.

\section{Results and Discussion}

\subsection{Hypothesis Testing}

The result of a prior analysis is provided in Table 1. It shows the standardized beta coefficient for $\mathrm{H}_{1}=0.715$ with a sig t-value $=0.000<0.05$. In addition, the coefficient beta for $\mathrm{H}_{2}$ and $\mathrm{H}_{3}$ is 0.678 and 0.208 , respectively. It implies that the three hypotheses proposed are accepted. Meanwhile, to understand the moderating role of work engagement $\left(\mathrm{H}_{4}\right)$, the Sobel test was applied. It shows the $t$ value of 11.741 and t-table of 1.968. This indicates that the leadership style has a positive and significant indirect influence on performance through the involvement of nurses' work, as evidenced by the value of influence not direct 0.477 , a total effect of 0.685 , and a significant level of 11.741 .

Based on the results of the study, the relationship model between variables can be described as follow Figure 1.

\subsection{Talent Management and Employee Performance}

Talent management is measured by talent development, recognition talent culture, policies, and leadership support (Aljunaibi, 2014). The finding of the research denoted that talent management had been delivered appropriately to nurses in Indonesia. Employees (nurses) think that the hospitals where they work pay attention to their future career 
Table 1: The Summary of Results Analysis

\begin{tabular}{|l|c|c|c|c|c|c|c|}
\hline & Variables & Direct Impact & $\begin{array}{c}\text { Indirect } \\
\text { Effect }\end{array}$ & Total & $\mathbf{t}$ & Sig. & Decision \\
\hline $\mathrm{H} 1$ & $\mathrm{X} \rightarrow \mathrm{Z}$ & .715 & - & .715 & 17.611 & .000 & accepted \\
\hline $\mathrm{H} 2$ & $\mathrm{X} \rightarrow \mathrm{Y}$ & .678 & - & .678 & 15.625 & .000 & accepted \\
\hline $\mathrm{H} 3$ & $\mathrm{Y} \rightarrow \mathrm{Z}$ & .208 & - & .208 & 4.801 & .000 & accepted \\
\hline $\mathrm{H} 4$ & ${ }^{*} \mathrm{X} \rightarrow \mathrm{Z} \rightarrow \mathrm{Y}$ & - & 0.477 & 0.685 & 11.741 & & accepted \\
\hline
\end{tabular}

Note: $X=$ talent management; $Y=$ employee performance; $Z$ = work engagement;

*the indirect impact was estimated using Sobel test $\left(\mathrm{t}_{\text {count }} \mathrm{t}_{\text {table }}\right)$

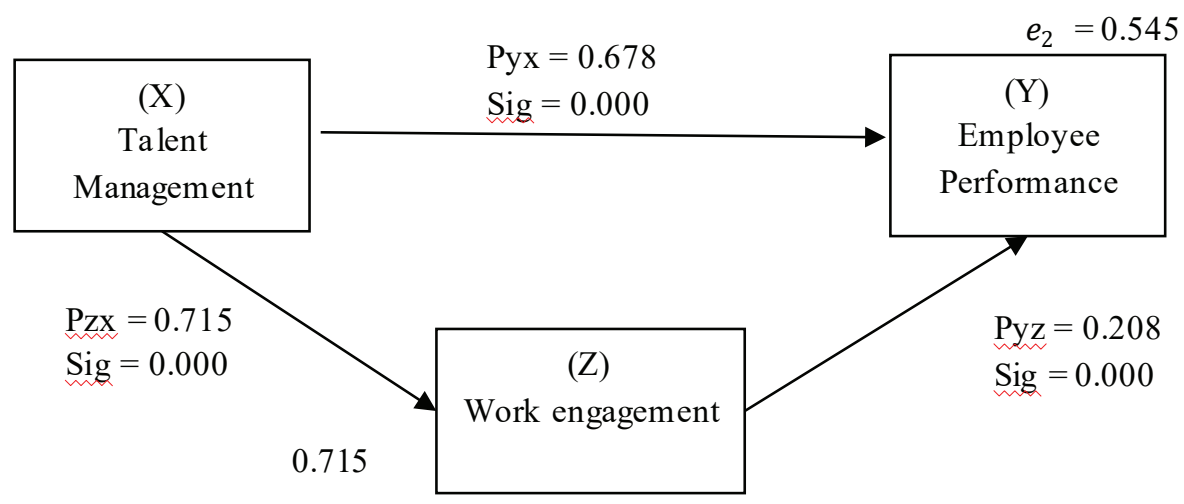

Figure 1: The Relationship between Variables

development and opportunities. Besides, nurses believed talent management optimized the best abilities, satisfied salary offered and benefits received. Furthermore, nurses do not want to change jobs; they are satisfied with the current workplace, they feel treated fairly, feel the work culture fits their conscience, they feel their quality of life is heeded, their aspirations are heard and cared for, even the leaders appreciate their performance.

On the other hand, nurse performance indicated by the quality of work, quantity of work, timeliness, work effectiveness, and attendance showed that the performance of Indonesian nurses is ranked high. Nurses can complete work according to the standards set by the hospital and are willing to work more than the standard time set to deliver excellent services to patients. They also try to maintain the quality of service to patients, complete their duties and obligations as a nurse, think fast, careful in solving work problems, willing to help new employees even if not asked, know and be able to use work facilities and equipment properly, work according to a standard operating procedure, and come to work earlier than work hours. In addition, they also prepare work well, go home from work according to the specified hours, and do not leave the office/workplace without permission from the leadership.
The results of the study confirm that talent management has a positive and significant effect on nurse performance in Indonesia. The results of the study support the numerous studies by Mkamburi and Kamaara (2017); Ndolo et al. (2017); Tash et al. (2016); Jyoti et al. (2011); Kamel (2019); Obeidat et al. (2018); Lubitsh and Smith (2007); Ingram and Gold (2016); Nojedeh and Ardabili (2015); Dahshan et al. (2018) which stated that effective talent management is considered as a critical success factor for organizations to gain sustainable competitive advantages. This implies that if the institution manages well the nurse's talent, it will lead to an increase in nurse's performance.

\subsection{Talent Management and Work Engagement}

Work engagement is measure by vigor, dedication, and absorption. The results showed that the attachment of Indonesian nurses was judged to be high. The nurses were enthusiastic and energized while at work, eager to go to work every day according to the rules of the hospital, considered necessary, and were proud to be a nurse, enjoying work as a nurse, and devoting all of their abilities at work. The finding of this study confirmed that talent management positively influences work engagement. This study is in line with a prior 
study by Bethke-Langenegger et al. (2011) that indicated that talent management at all levels focuses workers toward greater revenue. In addition, it allows work involvement to bring about higher achievement.

Moreover, Singh (2017) examined employees working in manufacturing companies in India. The finding showed that employee involvement and job satisfaction are two distinctive constructs found related to each other. Various evidence confirmed employee engagement forecast and job satisfaction, but little evidence found that job satisfaction leads to employee involvement. Indeed, Johnson (2000) suggested that organizational efforts improve social responsibility by increasing job satisfaction and will have an impact on job involvement. Satisfaction is a precursor for work attachment. Lastly, Abraham (2012) concluded that talent management influences satisfaction and satisfaction is a precursor of employee work engagement.

\subsection{Work Engagement and Employee Performance}

The third question in this study sought to determine the impact of work engagement and nurse achievement. According to the present results, the nurses' work engagement positively affects nurses' accomplishment. This finding is in agreement with the evidence of previous studies by Mohammed (2016), which stated that successful policies deal with attracting, developing, and retaining the talents of the organization. There is a link between talent management and employee involvement, retention, adding value, and ultimately increasing organizational performance. Talent management provides the potential for long-term competitive advantage (Lawler, 2008). Indeed, Rodriguez and Escobar (2010), further added that talent is the key to organizational success. Alnuqaidan and Ahmad (2019) prove there is no significant difference between low-talented and high-talented nurses in terms of their characteristics.

However, the quality of nursing care is better between the group of high-talented and non-talented nurses. Low-talented nurses can have talent abilities, but at different levels, such as mild, and moderate talent. Furthermore, Carter et al. (2016) concluded that self-efficacy and employee engagement were positively related to employee performance. Meanwhile, Anitha (2014) revealed that work engagement affects employee engagement. Al-momani (2018) revealed that the practice of employee engagement has a statistically significant effect on the performance of telecommunications employees in Jordan. Dajani (2015) concluded that employee engagement has a significant impact on employee performance, but has less impact on organizational commitment. Lastly, Lewiuci (2016) showed that employee work engagement affects employee performance.

\subsection{Talent Management, Employee Performance, and Work Engagement}

The last finding is that there is an indirect influence between talent management and employee performance. It implies that wok engagement plays an essential role in moderating between variables. The findings of this study confirmed that talent management at all employee levels that focus on driving revenue will result in employee involvement then improved performance. In addition, Ratnawati and Subudi (2018) proved that talent management influences employee retention through work engagement. This finding also confirms several works by Dhanalakshmi and Gurunathan (2014); Mensah et al. (2016) that proposed that talent management has a relationship with employee performance and it is mediated by several factors, such as affection and work engagement as well as how they identify with the company.

Besides, Mohammed (2016) remarked that talent managementhas a relationship with company accomplishment through work engagement. Kamel (2019) noted that talent management is a business strategy in an organization, which potentially promotes organization accomplishment. In other words, when worker or employee has particular competence that is difficult to be adopted by others, the organization will have a competitive advantage over its competitors. The results prove that talent management influences company performance through employee involvement. Indeed, Dahshan et al. (2018) believed that talent management influences hospital performance, while Al-Qeed et al. (2018) prove that talent management influences company performance through emotional intelligence. For this reason, talent management is an important program that needs to be implemented by an organization or a company.

\section{Conclusions}

This study aimed to examine the impact of talent management and employee performance. It also examined the role of work engagement in moderating talent management and employee achievement. The results show that the nurses' performance in hospitals, both government and private, is categorized as good, while the work engagement and talent management are also categorized as high. The findings of the study confirmed that talent management positively influences work engagement and employee performance. In the future, researchers need to focus on several matters, such as examining external and internal factors affecting nurses' performance. Moreover, further research is expected to be able to sort and compare hospital ownership. Government hospitals in Indonesia are divided into two categories, namely, those owned by the province and those owned by the 
regional government. It would be good if researchers further distinguish the two and compare them.

\section{References}

Abraham, S. (2012). Development of employee engagement programme on the basis of employee satisfaction survey. Journal of Economic Development, Management, IT, Finance, and Marketing, 4(1), 27-37.

Al-Momani, M. M. (2018). Exploring characteristics and perceptions of private hospital physician managers regarding their management training needs. Biomedical Research, 29(8), 1712-1717.

Al-Qeed, M. A., Khaddam, A. A. H., Al-Azzam, Z. F., \& Atieh, K. A. E. F. (2018). The effect of talent management and emotional intelligence on organizational performance: Applied study on pharmaceutical industry in Jordan. Journal of Business and Retail Management Research (JBRMR), 13(1), 1-14.

Alias, N. E., Noor, N., \& Hassan, R. (2014). Examining the mediating effect of employee engagement on the relationship between talent management practices and employee retention in the Information and Technology (IT) organizations in Malaysia. Journal of Human Resources Management and Labor Studies, 2(2), 227-242.

Aljunaibi, M. M. (2014). Talent management and employee engagement. Doctoral dissertation, The British University in Dubai (BUiD). Retrieved from https://bspace.buid.ac.ae/ handle/1234/704

Alnuqaidan, H. A., \& Ahmad, M. (2019). Comparison between Highly-Talented and Low-Talented Nurses on their Characteristics and Quality of Nursing Care. Diversity and Equality in Health and Care, 16(2), 30-35

Anitha, J. (2014). Determinants of employee engagement and their impact on employee performance. International Journal of Productivity and Performance Management, 63(3), 308-323. https://doi.org/10.1108/IJPPM-01-2013-0008

Barkhuizen, N., Mogwere, P., \& Schutte, N. (2014). Talent management, work engagement and service quality orientation of support staff in a higher education institution. Mediterranean Journal of Social Sciences, 5(4), 69-77. https://doi.org/10.5901/ mjss.2014.v5n4p69

Bethke-Langenegger, P., Mahler, P., \& Staffelbach, B. (2011). Effectiveness of talent management strategies. European Journal of International Management, 5(5), 524-539.

Bibi, M. (2019). Impact of talent management practices on employee performance. SEISENSE Journal of Management, 2(1), 22-32. https://doi.org/10.33215/sjom.v2i1.83

Carter, B., Danford, A., Howcroft, D., Richardson, H., Smith, A., \& Taylor, P. (2011). 'All they lack is a chain': lean and the new performance management in the British civil service. New Technology, Work and Employment, 26(2), 83-97. https://doi. org/10.1111/j.1468-005X.2011.00261.x
Dahshan, M., Keshk, L., \& Dorgham, L. S. (2018). Talent management and its effect on organization performance among nurses at shebin el-kom hospitals. International Journal of Nursing, 5(2), 108-123. https://doi.org/10.15640/jns.v5n2a10

Dajani, M. A. Z. (2015). The impact of employee engagement on job performance and organisational commitment in the Egyptian banking sector. Journal of Business and Management Sciences, 3(5), 138-147.

Dessler, G. (2015). Manajemen Sumber Daya Manusia. Jakarta: Salemba Empat.

Dhanalakshmi, R. V., \& Gurunathan, K. B. (2014). A study on talent management as a strategy to influence employee engagement and its affect on the organizational outcome. International Journal of Business and Administration Research Review, 2(4), 183-186.

Englert, B., \& Helmig, B. (2018). Volunteer performance in the light of organizational success: A systematic literature review. Voluntas: International Journal of Voluntary and Nonprofit Organizations, 29(1), 1-28. https://doi.org/10.1007/ s11266-017-9889-2

Hughes, J. C., \& Rog, E. (2008). Talent management: A strategy for improving employee recruitment, retention and engagement within hospitality organizations. International Journal of Contemporary Hospitality Management, 20(7), 743-757. https://doi.org/10.1108/09596110810899086

Ingram, T., \& Glod, W. (2016). Talent management in healthcare organizations-qualitative research results. Procedia Economics and Finance, 39, 339-346. https://doi.org/10.1016/S22125671(16)30333-1

Järvi, K., \& Khoreva, V. (2019). The role of talent management in strategic renewal. Employee Relations: The International Journal, 42(1), 75-89. https://doi.org/10.1108/ER-02-20180064

Johnson, J. W. (2000). A heuristic method for estimating the relative weight of predictor variables in multiple regression. Multivariate Behavioral Research, 35(1), 1-19. https://doi. org/10.1207/S15327906MBR3501_1

Jyoti, J., Sharma, R. D., \& Sharma, J. Y. O. T. I. (2011). Impact of talent management on employee effectiveness. The Indian Journal of Commerce, 64(2), 128.

Kamel, N. (2019). Implementing Talent Management and Its Effect on Employee Engagement and Organizational Performance. In Abu Dhabi International Petroleum Exhibition \& Conference. Society of Petroleum Engineers. https://doi. org/10.2118/197665-MS

Kim, M. S., \& Koo, D. W. (2017). Linking LMX, engagement, innovative behavior, and job performance in hotel employees. International Journal of Contemporary Hospitality Management, 29(12), 3044-3062. https://doi.org/10.1108/ IJCHM-06-2016-0319

Lawler, E. E. (2008). Strategic talent management: Lessons from the corporate world. Strategic Management of Human Capital, 5, 1-35. 
Lewiuci, P. G. (2016). Pengaruh employee engagement terhadap kinerja karyawan pada perusahaan keluarga produsen senapan angin. Agora, 4(2), 101-107.

Lubitsh, G., \& Smith, I. (2007). Talent management: A strategic imperative. The Ashridge Journal, 6, 1-6.

Mangusho, Y. S., Murei, R. K., \& Nelima, E. (2015). Evaluation of talent management on employees' performance in beverage industry: A case of delmonte Kenya Limited. International Journal of Humanities and Social Science, 5(8), 191-199.

Mathis. R. L., \& Jackson. J. H. (2006). Human Resource Management: Manajemen Sumber Daya Manusia. Jakarta: Salemba Empat.

Mensah, J. K., Bawole, J. N., \& Wedchayanon, N. (2016). Unlocking the "black box" in the talent management employee performance relationship: evidence from Ghana. Management Research Review, 39(12), 1546-1566. https://doi.org/10.1108/ MRR-08-2015-0190

Mkamburi, M. A. R. Y., \& Kamaara, D. M. (2017). Influence of Talent Management on Employee Performance at The United Nations: A Case of World Food Programme. The Strategic Journal of Business and Change Management, 2(3), 28-48.

Mogwere, P. G. (2014). The relationship between talent management, employee engagement and service quality of support staff in a South African Higher Education Institution (Doctoral dissertation). Retrieved from http://hdl.handle. net/10394/18106

Mohammed, A. (2016). The impact of talent management on employee engagement, retention and value addition in achieving organizational performance. International Journal of Engineering and Management, 1(12), 142-152.

Ndolo, F. M., Kingi, W. K., \& Ibua, M. P. (2017). Effect of talent management practices on employee performance among commercial based state corporations in Kenya. International Journal of Management and Commerce Innovations, 5(1), 580-591.

Nguyen, H. M., Nguyen, C., Ngo, T. T., \& Nguyen, L. V. (2019). The effects of job crafting on work engagement and work performance: A study of Vietnamese commercial banks.
Journal of Asian Finance, Economics and Business, 6(2), 189201. https://doi.org/10.13106/jafeb.2019.vol6.no2.189

Nojedeh, S. H., \& Ardabili, F. S. (2015). An overview on talent management in nursing. Management Issues in Healthcare System, 1, 4-17

Obeidat, D., Yousef, B., Yassin, H., \& Masa'deh, R. E. (2018). The Effect of Talent Management on Organizational Effectiveness in Healthcare Sector. Modern Applied Science, 12(11).

Ratnawati, D. P. D., \& Subudi, M. (2018). The impact of talent management toward employee retention with employee engagement as a mediator variable (Indonesian origin). E-Jurnal Manajemen, 7(11), 6299-6325. https://doi.org/10.24843/ EJMUNUD.2018.v07

Rodriguez, S. B., \& Escobar, I. (2010). Talents: the key for successful organizations. Doctoral Dissertation Linaeus University.

Schaufeli, W. B., Salanova, M., González-Romá, V., \& Bakker, A. B. (2002). The measurement of engagement and burnout: A two sample confirmatory factor analytic approach. Journal of Happiness Studies, 3(1), 71-92. https:// doi.org/10.1023/A:1015630930326

Schuler, R. S., Jackson, S. E., \& Tarique, I. (2011). Global talent management and global talent challenges: Strategic opportunities for IHRM. Journal of World Business, 46(4), 506-516. https://doi.org/10.1016/j.jwb.2010.10.011

Singh, L. (2017). Job satisfaction as a predictor of Employee engagement. Amity Global HRM Review, 7, 20-30.

Tash, M. S., Ali, E. N., \& Ahmadzadeh, M. (2016). The effects of talent management on employees' performance in oil jam petrochemical complex (Oil JPC): The mediating role of job satisfaction. International Journal of Economics and Finance, 8(6), 1-5. http://dx.doi.org/10.5539/ijef.v8n6p226

Tjiptono, F., \& Diana, A. (2003). Total quality management. Yogyakarta. Andi Publisher.

Yoon,K.H., Kim, B.Y., \& Eom, J. G.(2019). The effects ofjobcrafting on career success of multinational corporations' employees. Journal of Asian Finance, Economics and Business, 6(4), 213-225. https:// doi.org/10.13106/jafeb.2019.vol6.no4.213 